\title{
Frequency of Needle Stick Injury among Dental Students and Dentists of Karachi
}

\author{
${ }^{1}$ Kashif Ikram, ${ }^{2}$ Humayun Kaleem Siddiqui, ${ }^{3}$ Sana Maqbool, ${ }^{4}$ Maham Altaf, ${ }^{5}$ Sania Khan
}

\section{ABSTRACT}

Objective: To determine the frequency of needle stick injury in dental practice and to evaluate the level of knowledge, attitude and practices of the dental students and dentists regarding needle stick injuries prevention.

Materials and methods: This descriptive cross-sectional study was undertaken at eight different institutes of Karachi from July 2014 to March 2015. Data were collected in 800-sample questionnaire forms that comprised of ten questions in English language. Questionnaire was designed to obtain information regarding frequency, awareness and prevention of needle stick injury. Data were entered and analyzed in Statistical Package for the Social Sciences (SPSS) Version 20.

Result: A total of 800 samples were returned with a $100 \%$ response rate. About $73 \%$ participants gave a history of needle stick injury during practice. Of these $42 \%$ were the house officers. It was reported that knowledge regarding vaccination against hepatitis B was prevalent among participants. Most of the participants agreed that they have received guidelines regarding prevention and protection from needle stick injury.

Conclusion: It was concluded from this study that hepatitis B vaccination is necessary to prevent needle stick injury and proper instruments/guidelines should be given to all health related professionals in order to minimize the risk of bloodborne infections through needle stick injury.

Keywords: Dental professionals, Needle stick injury, Occupational hazards.

How to cite this article: Ikram K, Siddiqui HK, Maqbool S, Altaf M, Khan S. Frequency of Needle Stick Injury among Dental Students and Dentists of Karachi. World J Dent 2015;6(4): 213-216.

Source of support: Nil

Conflict of interest: None

${ }^{1}$ Principal, ${ }^{2} \mathrm{Head},{ }^{3}$ Research Analyst and Coordinator

${ }^{4,5}$ House Officer

1,2Department of Oral and Maxillofacial Surgery, Baqai Dental College, Baqai Medical University, Karachi, Sindh, Pakistan

${ }^{3}$ Department of Dental Education, Baqai Dental College Department of Public Health, Baqai Institute of Health Sciences Baqai Medical University, Karachi, Sindh, Pakistan

${ }^{4,5}$ Department of Oral and Maxillofacial Surgery, Baqai Dental College, Karachi, Pakistan

Corresponding Author: Sana Maqbool, Research Analyst and Coordinator, Department of Dental Education, Baqai Dental College Department of Public Health, Baqai Institute of Health Sciences Baqai Medical University, Karachi, Sindh, Pakistan, Phone: 0092331-0374307, e-mail: drsana.maqbool@gmail.com

\section{INTRODUCTION}

Needle stick injuries are wounds caused by needles that accidentally puncture the skin. Accidents with needles are one of the most common types of injury in the healthcare setting. ${ }^{1}$ Dentists, as well as other dental personnel are constantly exposed to a number of specific occupational hazards. They cause the appearance of various ailments, specific to the profession, which develop and intensify with years. ${ }^{2}$ Needle stick injury is the foremost cause for the spread of cross-infections. Exposure to bloodborne pathogens due to needle stick injuries in particular is a potential risk for healthcare workers, including dentist, dental students and dental staff. ${ }^{3}$

Needle stick injuries are a hazard for people who work with hypodermic syringes and other needle equipment. These injuries can occur at any time when people use, disassemble or dispose of needles.

Dentists and dental students are exposed to blood and other body fluids in the course of their work. Consequently, they are risk of infection with bloodborne viruses including human immunodeficiency virus (HIV), hepatitis $\mathrm{B}$ virus (HBV) and hepatitis $\mathrm{C}$ virus (HCV). ${ }^{4}$ The risk of infection for dentists depends on the prevalence of disease in the patient population, nature and frequency of exposures. ${ }^{5}$

While using needles and sharp instruments, injuries can happen at any time of procedure due to various reasons. ${ }^{6}$ An injury can occur when performing a procedure on a patient with a sharp instrument, when there is an unexpected movement by the patient or work colleague, or a momentary lack of concentration. ${ }^{7}$ Re-sheathing a used needle is a common cause of needle stick injuries. Even though a healthcare worker may have repeated the procedure many times, one slip can cause injury with potentially serious consequences. ${ }^{8}$

Inadequate staff, lack of experience, insufficient training, duty overload and fatigue may lead to occupational sharp injuries. ${ }^{9}$

It is estimated that approximately 600,000 to 800,000 needle stick injuries occur each year among healthcare workers in the United States. More than half of these injuries are not reported. In Pakistan, the incidence of needle stick injury is approximately $2.9 \%$ in general dental practitioners, $2.4 \%$ in undergraduates' students, 
$16.3 \%$ in faculty and $44.7 \%$ in house officers. ${ }^{10}$ The average percutaneous transmission rates for hepatitis $\mathrm{B}$ and $\mathrm{C}$ are $33.3 \%$ and $3.3 \%$ respectively. Administration of pre-exposure vaccination or postexposure prophylaxis is effective in preventing $\mathrm{HCV}$ infection. ${ }^{11}$ According to World Health Organization (WHO) study, the annual estimated proportions of healthcare workers (HCW) exposed to bloodborne pathogens globally were $2.6 \%$ for $\mathrm{HCV}, 5.9 \%$ for HBV and $0.5 \%$ for HIV corresponding to about $16,000 \mathrm{HCV}$ infections and 66,000 HBV infections in healthcare workers worldwide. ${ }^{12}$

So, the aim of this study was to determine the frequency of needle stick injury in dental practice and to evaluate the level of knowledge, attitude and practices of the dental students and dentists regarding needle stick injuries prevention.

\section{METHODOLOGY}

This descriptive cross-sectional study was carried out at eight different institutes of Karachi, Pakistan from July 2014 till March 2015. Undergraduates, house officers, faculty and general dental practitioners (GDPs) of various colleges were approached and after taking their consent, they were provided questionnaire forms which comprised of ten questions regarding knowledge, attitude and practices related to needle stick injury. Statistical Package for the Social Sciences (SPSS) Version 20 was used to analyze the data.

\section{RESULT}

A total of 800 questionnaires were returned from eight different institutes of Karachi, with a response rate of $100 \%$, in which 184 (23\%) were undergraduates, 337 (42.1\%) were house officers, 197 (24.6\%) were faculty and 82 (10.3\%) were general dental practitioners (Graph 1). Out of these, $585(73.1 \%)$ gave a history of needle stick injury during practice. Around 742 (92.8\%) participants were vaccinated

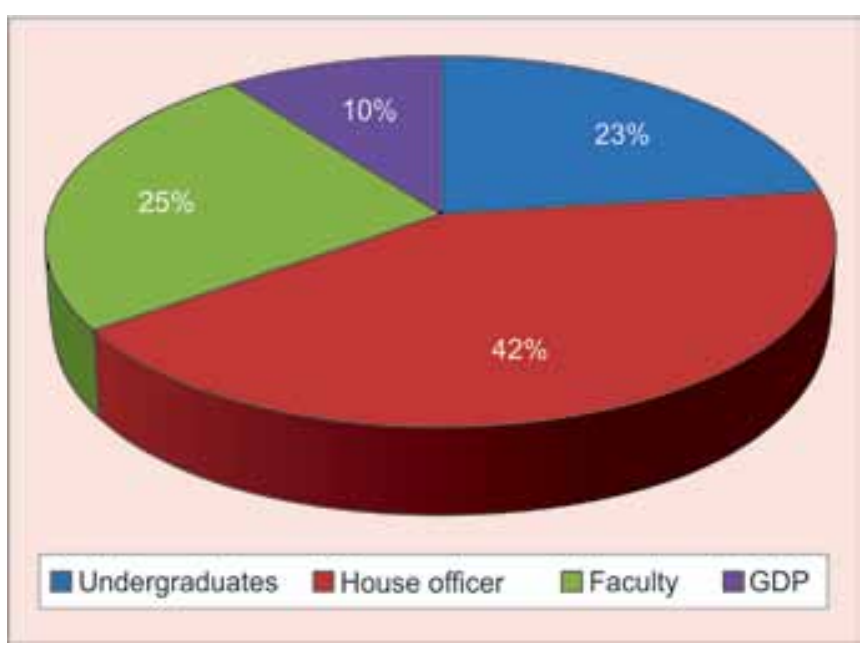

Graph 1: Frequency of number of participants in the study
Table 1: Frequency, knowledge and practice regarding needle stick injury

\begin{tabular}{|c|c|c|c|}
\hline Items & Yes & No & $\begin{array}{l}\text { Do not } \\
\text { know }\end{array}$ \\
\hline $\begin{array}{l}\text { Have you ever been inoculated } \\
\text { by needle during practice? }\end{array}$ & $73.1 \%$ & $24.5 \%$ & $2.4 \%$ \\
\hline $\begin{array}{l}\text { Are you vaccinated against } \\
\text { hepatitis } B \text { ? }\end{array}$ & $92.8 \%$ & $3.5 \%$ & $3.8 \%$ \\
\hline \multirow{2}{*}{$\begin{array}{l}\text { Have you ever been provided } \\
\text { with any instructions associated } \\
\text { with the risk of bloodborne } \\
\text { infections within the framework } \\
\text { of your clinical training? }\end{array}$} & $82.3 \%$ & $7.6 \%$ & $10.1 \%$ \\
\hline & Yes & No & May be \\
\hline $\begin{array}{l}\text { Do you think that the vaccination } \\
\text { you have received will protect } \\
\text { you from viral hepatitis? }\end{array}$ & $73.0 \%$ & $3.0 \%$ & $24.0 \%$ \\
\hline $\begin{array}{l}\text { Do surgical gloves reduce the } \\
\text { probability of NSI by the wearer? }\end{array}$ & $38.5 \%$ & $18.0 \%$ & $43.5 \%$ \\
\hline $\begin{array}{l}\text { Should needle be recapped } \\
\text { after use? }\end{array}$ & $51.0 \%$ & $4.8 \%$ & $44.3 \%$ \\
\hline You know PEP after NSI & $70.1 \%$ & $12.3 \%$ & $17.3 \%$ \\
\hline
\end{tabular}

for hepatitis B, among them 584 (73\%) participants were sure that vaccination will protect them from viral hepatitis, while 192 (24\%) were not sure. A total of $82 \%$ of the participants agreed that they have been provided with the instructions associated with the risk of bloodborne infections in clinical training. Of these, $38.5 \%$ participants agreed that a surgical glove reduces the probability of needle stick injury where as $43.5 \%$ did not agree with this.

The practice of recapping needle after use was still prevalent among the participant, i.e. 51\%. Some participants also revealed that they are not sure about recapping needle after use, i.e. $44 \%$ (Table 1 ).

When the participants asked about prevention of needle stick injury, $38 \%$ suggested that re-sheathing should be avoided, 34\% suggested that needle approximation should be done carefully and $27 \%$ suggested that needle should be placed in sharp container after being used. They also suggested that training and education (54\%) should be provided to the workers and protocols should be laid down in outpatient departments (OPDs) (40.5\%).

The action taken after needle stick injury included washing the site under tap water $(46 \%)$, history taking to the patient $(20 \%)$, no action $(24 \%)$, medical advice $(5 \%)$ and blood test (4\%) (Table 2).

It was good to note that about $70 \%$ of the participants that included undergraduates, house officers, faculty and general dental practitioners knew about the availability of post exposure prophylaxis (PEP) services after needle stick injury.

\section{DISCUSSION}

Needle stick injury is a matter of concern as it has been shown that needle stick injury is being a route of 
Table 2: Prevention of needle stick injury

\begin{tabular}{llllll}
\hline & None water & Medical advice & Blood test & History & Wash under tap \\
\hline $\begin{array}{l}\text { What safety } \\
\text { protocols did you } \\
\text { use after NSI? }\end{array}$ & $24.3 \%$ & $5.4 \%$ & $4.1 \%$ & $20.0 \%$ & $46.3 \%$ \\
& No re-sheathing & $\begin{array}{l}\text { Place the needle in sharp } \\
\text { containers }\end{array}$ & $\begin{array}{l}\text { Approximate needle } \\
\text { carefully } \\
34.4 \%\end{array}$ \\
$\begin{array}{l}\text { How can you } \\
\text { prevent NSI? }\end{array}$ & $38.3 \%$ & $27.4 \%$ & Do not know & \\
& $\begin{array}{l}\text { Training and } \\
\text { education }\end{array}$ & $\begin{array}{l}\text { OPDs } \\
\text { OPDols should be laid in }\end{array}$ & $5.1 \%$ & \\
$\begin{array}{l}\text { What suggestions } \\
\text { do you have for } \\
\text { preventing NSI? }\end{array}$ & $54.4 \%$ & $40.5 \%$ & & \\
\hline
\end{tabular}

transmission of certain potential detrimental diseases. Our findings indicate that house officers from different institutes of Karachi are at high risk of needle stick injury i.e. $42 \%$ followed by faculty and general dental practitioners that is 25 and $23 \%$ respectively. One study indicates that in private hospitals needle stick injuries are more common in doctors as paramedical staff strictly follow the protection protocols. Other studies have also shown higher prevalence of needle stick injuries in residents and junior dentists. ${ }^{3}$

Aeeza Malik et al study from Nepal reported 74\% needle stick injury among dental practitioners and staff, while in a research conducted in Iran it was 39.4\%. ${ }^{13}$ Many researchers have analyzed needle stick injuries among healthcare professionals and not only on general dental practitioners. Their results illustrated that $74 \%$ of participants know about precautions concerning needle stick injuries. $^{13}$

Aslam $\mathrm{M}$ et al showed that $34 \%$ of participants with needle stick injury were exposed to needles that were contaminated with fluid of hepatitis B or C patients, which is alarming because it has been observed that large number of hepatitis infection occur as a result of needle stick injury. ${ }^{3}$

In our study, it has been observed that $82 \%$ participants were provided with instructions associated with the risk of bloodborne infections in their clinical training. However, $93 \%$ of participants have the knowledge about vaccination and $73 \%$ were confident that vaccination would protect them from viral hepatitis.

In a study of Sumathi Muralidhar et al revealed that $74 \%$ of healthcare workers were using gloves at a time of needle stick injury, a figure which fell short of the figures shown by Askarian et al (96.2\%) in Iran. ${ }^{8}$ However, in our study $38.5 \%$ of the participants agreed that gloves reduces the probability of needle stick injury where as $43.5 \%$ of the participants were not sure about it.

\section{CONCLUSION}

It was concluded from this study that hepatitis B vaccination is necessary to prevent needle stick injury and proper instruments/guidelines should be given to all health related professionals in order to minimize the risk of bloodborne infections through needle stick injury.

\section{REFERENCES}

1. Martins AM, Santos NC, Lima MD, Pereira RD, Ferreira R. Needle stick and sharp instrument injuries among dentists in Montes Claros, Brazil. Arquivos Odontol 2010;46(3):127-135.

2. Gupta N, Tak J. Needles stick injuries in dentistry. Kathmandu University Med J 2011;35(3):208-212.

3. Aslam M, Taj T, Ali A, Mirza W, Ali H, Dar M, Badar N. Needle stick injuries among health care workers of public sector tertiary care hospitals of Karachi. J College Physic Surg, Pakistan 2010;20(3):150-153.

4. Ahmad A, Ali T, Ghazi A, Younus Khan M, Ali Z. Needle sticks injury and associated factors among medical students. Pakistan J Surg 2008;24(3):145-149.

5. Trim JC, Elliott, et al. A review of sharp injuries and preventive strategies. J Hosp Inf 2003;53(4):237-242.

6. Kapoor K, Gambhir RS, Singh S, Gill S, Singh A. Knowledge, awareness and practice regarding needle stick injuries in dental profession in India: a systematic review. Niger Med J 2013 Nov-Dec;54(6):365-370.

7. Moazzam A, Salem ZA. Griffith BR. Needle stick injuries: an overview of the size of the problem, prevention and management, occupational and environmental health and safety, Sheikh Khalifa Medical City, Abu Dhabi, United Arab Emirates. J Med Biomed Sci 2010;2(2):53-61.

8. Muralidhar S, Singh RK, Malhotra J, Bala MM. Needle stick injuries among health care workers in a tertiary care hospital of India. Ind J Med Res 2010 Mar;131:405-410.

9. Askarian M, Malekmakan L, Memish ZA. Prevalence of needle stick injuries among dental, nursing and midwifery students in Shiraz, Iran GMS. Krankenhhyg-Interdiszip 2012;7(1).

10. Zuberi BF, Zuberi FF, Hasan SR, Kumar R, Memon SA, Afsar S. Frequency of acute hepatitis $C$ after needle stick 
injury and its treatment outcome. Pak J Med Sci 2009;25(5): 766-769.

11. Sjostrom TH, Skyman E, Hellström L, Kula M, Grinevika V. Cross-infection prevention, basic hygiene practices and education within nursing and health care in Latvia: a Swedish-Latvian practice development project. Nurse Educ Today 2003;23(6):404-411.
12. Sharma R, Rasania SK, Singh S. Study of prevalence and response to needle stick injuries among healthcare workers in a Tertiary Care Hospital in Delhi, India. Ind J Community Med 2010 Jan;35(1):74-77.

13. Malik A, Shaukat MS, Qureshi A. Needle stick injury: a rising bio-hazard. J Ayub Medical College, Abbottabad 2012; 24(3-4):144-146. 